University of New Hampshire

University of New Hampshire Scholars' Repository

Faculty Publications

2-14-2003

\title{
Experimentally induced root mortality increased nitrous oxide emission from tropical forest soils
}

\author{
Ruth K. Varner \\ University of New Hampshire, Durham, ruth.varner@unh.edu \\ Michael Keller \\ USDA Forest Service \\ Jillan R. Robertson \\ University of New Hampshire, Durham \\ Jadson D. Dias \\ Fundacao Floresta Tropical, Santarem \\ Hudson Silva \\ University of New Hampshire, Durham
}

See next page for additional authors

Follow this and additional works at: https://scholars.unh.edu/faculty_pubs

Comments

This is an article published by AGU in Geophysical Research Letters in 2003, available online: https://dx.doi.org/

10.1029/2002GL016164

\section{Recommended Citation}

Varner, R.K., M. Keller, *J.R. Robertson, J.D. Dias, ${ }^{\circ}$ H. Silva, P.M. Crill, 'M. McGroddy and W.L. Silver (2003), Experimentally induced root mortality increased nitrous oxide emission from tropical forest soils, Geophys. Res. Lett., 30, 10.1029/2002GL016164.

This Article is brought to you for free and open access by University of New Hampshire Scholars' Repository. It has been accepted for inclusion in Faculty Publications by an authorized administrator of University of New Hampshire Scholars' Repository. For more information, please contact Scholarly.Communication@unh.edu. 


\section{Authors}

Ruth K. Varner, Michael Keller, Jillan R. Robertson, Jadson D. Dias, Hudson Silva, Patrick M. Crill, Megan E. McGroddy, and Whendee L. Silver 


\title{
Experimentally induced root mortality increased nitrous oxide emission from tropical forest soils
}

\author{
Ruth K. Varner, ${ }^{1}$ Michael Keller, ${ }^{1,2}$ Jillana R. Robertson, ${ }^{1}$ Jadson D. Dias, ${ }^{3}$ \\ Hudson Silva, ${ }^{1,3}$ Patrick M. Crill, ${ }^{1}$ Megan McGroddy, ${ }^{4}$ and Whendee L. Silver ${ }^{5}$ \\ Received 23 August 2002; revised 3 October 2002; accepted 15 November 2002; published 14 February 2003.
}

[1] We conducted an experiment on sand and clay tropical forest soils to test the short-term effect of root mortality on the soil-atmosphere flux of nitrous oxide, nitric oxide, methane, and carbon dioxide. We induced root mortality by isolating blocks of land to $1 \mathrm{~m}$ using trenching and root exclusion screening. Gas fluxes were measured weekly for ten weeks following the trenching treatment. For nitrous oxide there was a highly significant increase in soil-atmosphere flux over the ten weeks following treatment for trenched plots compared to control plots. $\mathrm{N}_{2} \mathrm{O}$ flux averaged 37.5 and $18.5 \mathrm{ng} \mathrm{N}$ $\mathrm{cm}^{-2} \mathrm{~h}^{-1}$ from clay trenched and control plots and 4.7 and $1.5 \mathrm{ng} \mathrm{N} \mathrm{cm}^{-2} \mathrm{~h}^{-1}$ from sand trenched and control plots. In contrast, there was no effect for soil-atmosphere flux of nitric oxide, carbon dioxide, or methane. INDEX TERMS: 0315 Atmospheric Composition and Structure: Biosphere/atmosphere interactions; 1615 Global Change: Biogeochemical processes (4805); 1610 Global Change: Atmosphere (0315, 0325); 0394 Atmospheric Composition and Structure: Instruments and techniques. Citation: Varner, R. K., M. Keller, J. R. Robertson, J. D. Dias, H. Silva, P. M. Crill, M. McGroddy, and W. L. Silver, Experimentally induced root mortality increased nitrous oxide emission from tropical forest soils, Geophys. Res. Lett., 30(3), 1144, doi:10.1029/2002GL016164, 2003.

\section{Introduction}

[2] Soil-atmosphere exchange of carbon dioxide $\left(\mathrm{CO}_{2}\right)$, nitric oxide $(\mathrm{NO})$, nitrous oxide $\left(\mathrm{N}_{2} \mathrm{O}\right)$ and methane $\left(\mathrm{CH}_{4}\right)$, is controlled by complex biogeochemical processes [Con$\mathrm{rad}, 1996]$. The soils of tropical forests are globally important sources of $\mathrm{N}_{2} \mathrm{O}$ and NO [Matson et al., 1990; Davidson and Kingerlee, 1997]. Tropical forest soils can change from a sink to a source of $\mathrm{CH}_{4}$ depending upon soil moisture conditions and land use [Keller and Reiners, 1994; Steudler et al., 1996].

[3] Previous studies in tropical forests soils in Brazil, Costa Rica, and Puerto Rico suggested that root mortality increases emissions of $\mathrm{NO}$ and $\mathrm{N}_{2} \mathrm{O}$ from the soil

\footnotetext{
${ }^{1}$ Complex Systems Research Center, Institute for the Study of Earth Oceans and Space, University of New Hampshire, Durham, New Hampshire, USA.

${ }^{2}$ USDA Forest Service, International Institute of Tropical Forestry, Rio Piedras, Puerto Rico.

${ }^{3}$ Fundacao Floresta Tropical, Santarem, Para, Brazil.

${ }^{4}$ Department of Ecology and Evolutionary Biology, Princeton University, Princeton, New Jersey, USA.

${ }^{5}$ Division of Ecosystem Sciences, Department of Environmental Science, Policy, and Management, University of California, Berkeley, California, USA.
}

Copyright 2003 by the American Geophysical Union. 0094-8276/03/2002GL016164 surface [Matson et al., 1990; Keller et al., 2000]. In these studies, the effect of root mortality was inferred from observations of increased trace gas emissions following the emplacement of bases for soil enclosures to depths of 1 to $2 \mathrm{~cm}$ into the soil surface. The emplacement procedure cut roots. In Brazil, Matson et al. [1990] found that $\mathrm{N}_{2} \mathrm{O}$ fluxes measured from permanently installed chamber bases showed significant increases compared to fluxes from control bases emplaced immediately before measurement after only 5 hours of insertion of the first set of bases. In Costa Rica and Puerto Rico, Keller et al. [2000] observed increased fluxes of $\mathrm{NO}$ and $\mathrm{N}_{2} \mathrm{O}$ from several hours up to 6 weeks after base emplacement.

[4] In order to provide a more direct test of the effect of root mortality on the soil-atmosphere exchange of trace gases $\left(\mathrm{CO}_{2}, \mathrm{NO}, \mathrm{N}_{2} \mathrm{O}\right.$ and $\left.\mathrm{CH}_{4}\right)$, we established a series of plots, intended to kill all roots within the plots, in the Tapajos National Forest, Brazil. We evaluate the effect of the experimentally induced root mortality on trace gas exchange in clay and sand soil in tropical forest.

\section{Methods}

\subsection{Study Area}

[5] The study site in the Tapajos National Forest (TNF) is near $\mathrm{km} 83$ on the Santarem-Cuiaba Highway south of Santarem, Para, Brazil. The region receives approximately $2000 \mathrm{~mm}$ of precipitation per year and has an annual mean temperature of $25^{\circ} \mathrm{C}$ [Silver et al., 2000]. Vegetation at the site is evergreen, mature tropical forest with a total biomass of about $372 \mathrm{Mg} \mathrm{ha}^{-1}$ [Keller et al., 2001]. We located experiments on contrasting soils, a clay textured Oxisol (80\% clay, $18 \%$ sand, $2 \%$ silt) and a sand textured Ultisol (60\% sand, $38 \%$ clay, $2 \%$ silt) [Silver et al., 2000].

\subsection{Experimental Design}

[6] The experiment was a randomized complete block design. For each soil type, 5 pairs of $2.5 \times 2.5 \mathrm{~m}$ plots were located so that there were no trees greater than 10 $\mathrm{cm}$ diameter at breast height $(\mathrm{DBH} ; 1.3 \mathrm{~m})$ on the plots. One plot in each pair was randomly selected for trenching. In the trenched plots, trenches were dug to $1 \mathrm{~m}$ depth and were lined with a fine stainless steel mesh $(<0.5 \mathrm{~mm})$ to prevent the penetration of roots while allowing the movement of water and gases. All vegetation was clipped from the trenched plots at the time of trenching and every two weeks thereafter to prevent colonization of the plot by live roots. We completed the trenching operations in the period from Julian day 147 
through 156 in 2000 (May 27 through June 4). For all plots, we made measurements in an interior square region, $2 \times 2 \mathrm{~m}$ that was surrounded by a $0.5 \mathrm{~m}$ wide buffer strip.

\subsection{Trace Gas Flux Measurement}

[7] We measured the soil-atmosphere fluxes of $\mathrm{CO}_{2}$, $\mathrm{NO}, \mathrm{N}_{2} \mathrm{O}$ and $\mathrm{CH}_{4}$ weekly for approximately 10 weeks following the trenching treatment. Two chamber bases were inserted approximately $2 \mathrm{~cm}$ depth in the soil at randomly selected points in the sampled plots within 30 minutes of the weekly flux measurement. These chamber bases were removed immediately after flux measurements were completed. Dynamic flow-through chambers were used for measurement of $\mathrm{NO}$ and $\mathrm{CO}_{2}$ and static vented chambers were used for measurements of $\mathrm{N}_{2} \mathrm{O}$ and $\mathrm{CH}_{4}$ Keller and Reiners [1994]. The measurement of these two pairs of gases was sequential after lifting the chamber top to equilibrate the headspace with ambient air.

[8] We used an integrated backpack system to measure $\mathrm{NO}$ and $\mathrm{CO}_{2}$ over 3 to 10 minutes from enclosures. The flow through the chamber was regulated to about $300 \mathrm{~cm}^{3}$ $\min ^{-1}$. Air entered the chamber through a chimney-like air-gap that was specifically designed to minimize exchange with the outside air and to avoid pressure fluctuations within the chamber. Rayment and Jarvis [1997] found that the pressure differential between the chamber and the outside air was less than $0.004 \mathrm{~Pa}$ in laboratory tests.

[9] Air flowed from the soil enclosure through a Teflon-lined polyethylene sample line $30 \mathrm{~m}$ in length and then it entered an infrared gas analyzer (Li-Cor 6262) for $\mathrm{CO}_{2}$ measurement. From the Li-6262, the sampled air then passed through a flow control manifold where it was mixed with a make-up air flow of about $1200 \mathrm{~cm}^{3} \mathrm{~min}^{-1}$ and a flow of NO (1 ppm) standard gas that varied from 3 to $10 \mathrm{~cm}^{3} \mathrm{~min}^{-1}$ as measured on an electronic mass flowmeter (Sierra Top-Trak). The make-up air and standard addition maintain optimum and linear performance of the $\mathrm{NO}_{2}$ chemiluminescent analyzer (Scintrex LMA-3). The mixed sample stream passed through a $\mathrm{Cr}_{2} \mathrm{O}_{3}$ catalyst for conversion of $\mathrm{NO}$ to $\mathrm{NO}_{2}$ [Levaggi et al., 1974]. The $\mathrm{NO}_{2}$ chemiluminescent analyzer was standardized by a two-point calibration approximately hourly. We checked the intra-day stability of the calibration on each sampling date by comparison of each standard run to a linear interpolation between the standards runs at the beginning and end of the daily measurement period. We also compared the concentration of the field NO standard periodically with laboratory standards to assure that they did not drift [Veldkamp and Keller, 1997]. Signals from the $\mathrm{CO}_{2}$ and $\mathrm{NO}_{2}$ analyzers and the mass flow meter for the NO standard gas were recorded on a datalogger (Campbell CR10). Fluxes were calculated from the linear increase of concentration versus time.

[10] Static enclosure measurements were made for $\mathrm{CH}_{4}$ and $\mathrm{N}_{2} \mathrm{O}$ fluxes using the same bases and vented caps [Keller and Reiners, 1994]. Four enclosure headspace samples were taken over a 30-minute sampling period with $20 \mathrm{ml}$ nylon syringes. Analysis of grab samples for $\mathrm{CH}_{4}$ and $\mathrm{N}_{2} \mathrm{O}$ were completed within 36 hours by FID and ECD gas chromatography. Gas concentrations were calculated by comparing peak areas for samples to those for standards.

\subsection{Additional Measurements}

[11] Soil samples were taken to $10 \mathrm{~cm}$ depth in each plot on each date for determination of soil moisture (oven dried at $105^{\circ} \mathrm{C}$ ). Soil moisture was expressed as waterfilled-pore-space (WFPS) using soil bulk densities of 1.34 and 1.02 for sand and clay soils respectively [Silver et al., 2000].

\subsection{Fine Root Sampling and Analysis}

[12] Roots were sampled using a root corer with a $6 \mathrm{~cm}$ internal diameter [Vogt and Persson, 1991]. Cores were removed to $10 \mathrm{~cm}$ depth on 2 dates (June 4 (day 156) and 30 (day 182)) following trenching. Roots were sorted and dried at $65^{\circ} \mathrm{C}$ and weighed.

\subsection{Data Analysis}

[13] To analyze differences in a randomized complete block design, we reduced the flux, moisture and root biomass data to plot means for the entire experimental period. We compared plot means using a two-way ANOVA within each soil type testing for differences for treatment and plot with no interactions. For $\mathrm{N}_{2} \mathrm{O}$ and root biomass, we $\log$ transformed the means prior to analysis to homogenize the variances. For the cases of $\mathrm{NO}, \mathrm{CO}_{2}$, and $\mathrm{CH}_{4}$ we also checked for treatment differences within each soil type by running a two-way ANOVA for each gas on each date.

\section{Results}

\subsection{Stability of NO Standardization}

[14] NO standards were run in the field at the beginning and end of 8 enclosure flux samples or approximately every hour. NO standard response calculated using a linear fit of the two standards encompassing the measurement period was compared to the frequent (generally hourly) standardization. A given hourly standard run varied by as much as $60 \%$ from the standard response calculated from the linear fit (Figure 1). On two dates of eight tested, at least $50 \%$ of the standards fall outside of the predicted standard response based on the starting and ending standards by at least $20 \%$. On two other dates at least $10 \%$ of the standard runs fall outside of this $\pm 20 \%$ window.

\subsection{Trace Gas Fluxes}

[15] Trace gas fluxes and soil WFPS over the ten weeks of the trenching experiment are shown in Figures 2 and 3. Because of equipment malfunction, we did not measure $\mathrm{NO}$ and $\mathrm{CO}_{2}$ flux on the final study date, day 227 (August 14). Analysis of variance of data reduced to plot mean within each soil type showed no significant differences for fluxes of $\mathrm{CO}_{2}, \mathrm{CH}_{4}$, NO or soil WFPS for treatment or plot effect on both soil types. Additional tests with ANOVA on each individual treatment date showed no significant effects.

[16] For both sand and clay soils $\mathrm{N}_{2} \mathrm{O}$ fluxes from the trenched plots significantly exceeded fluxes from the controls over the experimental period $(\mathrm{p}<0.001)$ (Figure 3$)$. 


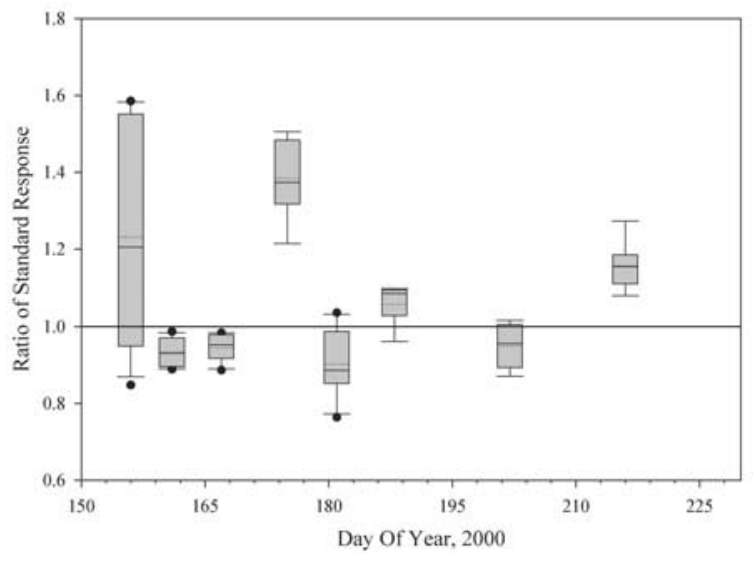

Figure 1. Ratio of NO standard response at a given time compared to response calculated from a linear fit of the first and final standards versus time on a given day. Closed circles represent all data that lie outside the 10th and 90th percentiles, error bars represent the 10th and 90th percentiles, the 25th and 75th percentiles are the ends of the shaded box with the 50th percentile represented by the solid line. The dashed line is the arithmetic mean. Data from Julian day 195 (July 13) has been omitted because there were few samples that day and only two standards run.

$\mathrm{N}_{2} \mathrm{O}$ flux from the trenched plots averaged 37.5 and $4.7 \mathrm{ng}$ $\mathrm{N} \mathrm{cm}{ }^{-2} \mathrm{~h}^{-1}$ from clay and sand soils respectively. These fluxes exceeded average control fluxes by more than a factor of 2 (18.5 and $1.5 \mathrm{ng} \mathrm{N} \mathrm{cm}{ }^{-2} \mathrm{~h}^{-1}$ from clay and
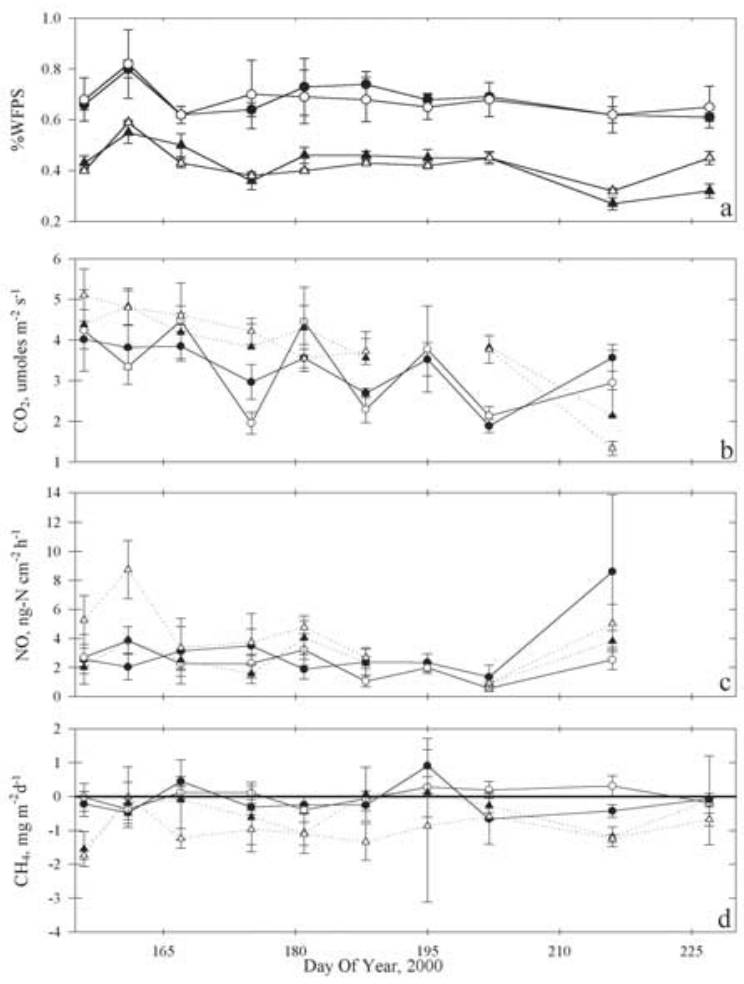

Figure 2. Measurements of (a) percent water-filled pore space (\%WFPS), (b) $\mathrm{CO}_{2}$, (c) $\mathrm{NO}$, and (d) $\mathrm{CH}_{4}$ fluxes from day 158 (June 6) through 227 (August 14) 2000 for clay (•), clay trench $(\bigcirc)$, sand $(\mathbf{\Delta})$, and sand trench $(\triangle)$ sites. Error bars are the standard error for plots $(n=5)$.
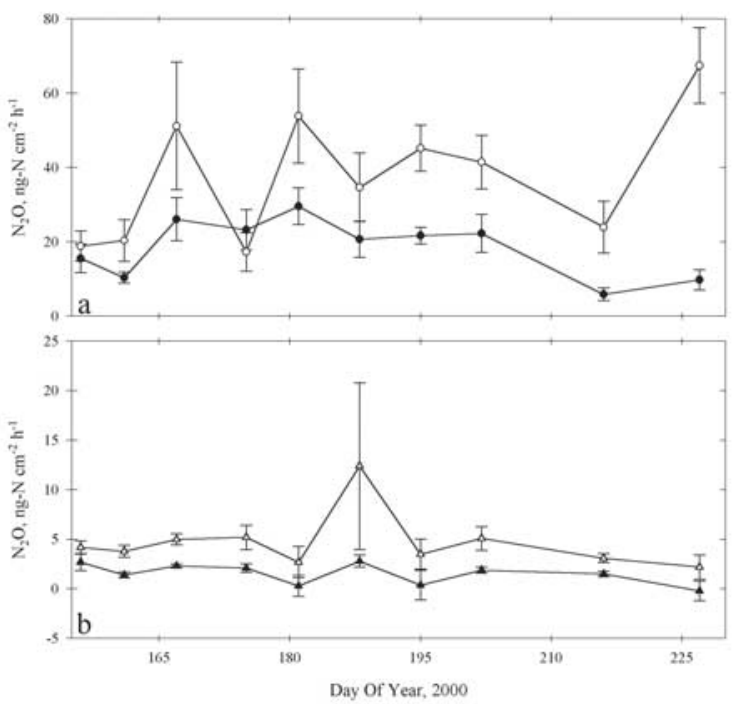

Figure 3. $\mathrm{N}_{2} \mathrm{O}$ flux measurements for the (a) clay and (b) sand plots. Symbols and error bars as in Figure 2.

sand soils respectively) over the 10 weeks following the trenching treatment.

\subsection{Root Biomass}

[17] Root biomass in the trenched plots averaged 222 $( \pm 25) \mathrm{g} \mathrm{m}^{-2}$ in the clays and $260( \pm 25) \mathrm{g} \mathrm{m}^{-2}$ in the sands. Root biomass decreased slightly over the first four weeks following trenching in the clay soils to $173( \pm 21) \mathrm{g} \mathrm{m}^{-2}$. In contrast, root biomass increased slightly in the sand trench plots following root mortality to $277( \pm 30) \mathrm{g} \mathrm{m}^{-2}$, possibly resulting from colonization by decomposers [Silver and Vogt, 1993]. In both cases, the differences in root biomass where not statistically significant.

\section{Discussion}

\subsection{Data Quality for NO Fluxes}

[18] It has been common practice to standardize the Scintrex LMA-3 instrument when used for measurement of soil-atmosphere NO flux, only at the beginning and the end of the sampling period in a laboratory near the field site [e.g., Verchot et al., 1999; Garcia-Montiel et al., 2001]. This practice avoids the need to transport a compressed gas cylinder to the field. Often 4 to 8 hours or more pass between standardizations. Using field standards at nearly hourly intervals, we found that on 2 of 8 sampling dates, that standardization based on a linear interpolation of standard response from standards taken prior to and following sampling would have caused an error greater than $20 \%$ in the measured NO fluxes more than half the time (Figure 1). Moreover, on those dates, individual field standards could vary by as much as $60 \%$ from the linear interpolation of the first and last standardization.

[19] We have taken precautions to minimize the variability inherent in our operation of the Scintrex LMA-3. In particular, we maintain the system within its designed linear range ( 3 to $50 \mathrm{ppbv}$ ) by use of a standard addition. We also maintain a relatively constant relative humidity over the $\mathrm{CrO}_{3}$ catalyst. Tests using $\mathrm{CrO}_{3}$ catalysts for conversion of $\mathrm{NO}$ to $\mathrm{NO}_{2}$ show that the catalysts are sensitive to relative 
humidity changes and that they function most efficiently in the range $35 \%$ to $80 \%$ relative humidity. Oxidation efficiency drops for higher relative humidity levels [Levaggi et al., 1974; Hutchinson et al., 1999]. Frequent field standardization of the LMA-3 is necessary.

\subsection{Effects of the Trenching Treatment on $\mathrm{N}_{2} \mathrm{O}$ Fluxes}

[20] Root mortality may have caused a decrease in oxygen in the rhizosphere because of the oxygen demand from increased decomposition. Lack of oxygen tends to increase the production of $\mathrm{N}_{2} \mathrm{O}$ whether through nitrifier-denitrification or through denitrification. So-called "hotspots" of organic decomposition, have been shown to support rapid rates of $\mathrm{N}_{2} \mathrm{O}$ production in experiments with soil cores [Parkin, 1987]. Additionally, root decay and lack of plant nutrient uptake can lead to nitrate concentration buildup [Silver and Vogt, 1993] and therefore more $\mathrm{N}$ available for $\mathrm{N}_{2} \mathrm{O}$ production. Root mortality and the initial stages of decay are likely to result in the release of soluble $\mathrm{C}$ that can stimulate $\mathrm{N}_{2} \mathrm{O}$ production.

[21] Soil $\mathrm{N}_{2} \mathrm{O}$ emissions from plots treated by trenching significantly exceeded emissions from control plots by a factor of 2 for 10 weeks following trenching. The trenching treatment did not increase soil moisture content. Root mortality and the complex of biogeochemical changes in the rhizosphere surrounding dead roots is the likely cause of the doubled $\mathrm{N}_{2} \mathrm{O}$ emissions. Root mortality and turnover is an ongoing process in soils. Fine roots $(\leq 2 \mathrm{~mm})$ have a lifetime of months to a few years depending upon the environment [Gill and Jackson, 2000; Silver and Miya, 2001]. The possible effect of root mortality on the production and flux of $\mathrm{N}_{2} \mathrm{O}$ from soils has not been considered in recent simulation models of soil $\mathrm{N}_{2} \mathrm{O}$ production and emission such as DNDC [Li et al., 2000], CASA [Potter et al., 1996] or DAYCENT [Parton et al., 2001]. Given that models of $\mathrm{N}_{2} \mathrm{O}$ emissions still fail to reliably simulate a wide range of field conditions [Frolking et al., 1998] this cause of $\mathrm{N}_{2} \mathrm{O}$ production merits further investigation.

[22] Acknowledgments. We acknowledge the Brazilian Ministry of Science and Technology (MCT) and the LBA Central Office (INPE/ CPTEC) for leadership and organization of the LBA. We thank Bethany Reed and the staff of the Santarem Office for their dedication and support in the field. This work received financial support from the NASA Terrestrial Ecology Program (NCC5-225, NCC5-357), the USDA Forest Service and USAID.

\section{References}

Conrad, R., Soil microorganisms as controllers of atmospheric trace gases $\left(\mathrm{H}_{2}, \mathrm{CO}, \mathrm{CH}_{4}, \mathrm{OCS}, \mathrm{N}_{2} \mathrm{O}\right.$, and NO), Microbiol. Reviews, 60, 609-640, 1996

Davidson, E. A., and W. Kingerlee, A global inventory of nitric oxide emissions from soils, Nutrient Cycl. Agroecosystems, 48, 37-50, 1997.

Frolking, S. E., et al., Comparison of $\mathrm{N}_{2} \mathrm{O}$ emissions from soils at three temperate agricultural sites: Simulations of year-round measurements by four models, Nutrient Cycl. Agroecosystems, 52, 77-105, 1998.
Garcia-Montiel, D. C., et al., Controls on soil nitrogen oxide emissions from forest and pastures in the Brazilian Amazon, Global Biogeochem. Cycles, 15, 1021-1030, 2001.

Gill, R. A., and R. B. Jackson, Global patterns of root turnover for terrestrial ecosystems, New Phytologist, 147, 13-31, 2000.

Hutchinson, G. L., et al., Overcoming humidity dependence of the chromium trioxide converter used in luminol-based nitric oxide detection, Atmos. Environ., 33, 141-145, 1999.

Keller, M., and W. A. Reiners, Soil-atmosphere exchange of nitrous oxide, nitric oxide, and methane under secondary succession of pasture to forest in the Atlantic lowlands of Costa Rica, Global Biogeochem. Cycles, 8, 399-410, 1994.

Keller, M., et al., Soil-atmosphere nitrogen oxide fluxes: Effects of root disturbance, J. Geophys. Res., 105, 17,693-17,698, 2000.

Keller, M., et al., Biomass in the Tapajos National Forest, Brazil: Examination of sampling and allometric uncertainties, Forest Ecol. Manage., 154, $371-382,2001$.

Levaggi, D., et al., Quantitative analysis of nitric oxide in presence of nitrogen dioxide at atmospheric concentrations, Environ. Sci. Tech., 8, $348-350,1974$

$\mathrm{Li}, \mathrm{C}$., et al., A process-oriented model of $\mathrm{N}_{2} \mathrm{O}$ and $\mathrm{NO}$ emissions from forest soils: 1, Model development, J. Geophys. Res., 105, 4369-4384, 2000.

Matson, P. A., et al., Sources of variation in nitrous oxide flux from Amazonian ecosystems, J. Geophys. Res., 95, 16,789-16,798, 1990.

Parkin, T. B., Soil microsites as a source of denitrification variability, Soil Sci. Soc. Am. J., 51, 1194-1199, 1987.

Parton, W. J., et al., A generalized model for $\mathrm{NO}_{\mathrm{x}}$ and $\mathrm{N}_{2} \mathrm{O}$ emissions from soils, J. Geophys. Res., 106, 17,403-17,419, 2001

Potter, C. S., et al., Process modeling of controls on nitrogen trace gas emissions from soils worldwide., J. Geophys. Res., 101, 1361-1377, 1996.

Rayment, M. B., and P. G. Jarvis, An improved open chamber system for measuring soil $\mathrm{CO}_{2}$ effluxes in the field, J. Geophys. Res., 102, 28,77928,784, 1997

Silver, W. L., and R. K. Miya, Global patterns in root decomposition: Comparisons of climate and litter quality effects, Oecologia, 129, 407-419, 2001

Silver, W. L., and K. A. Vogt, Fine root dynamics following single and multiple disturbances in a subtropical wet forest ecosystem, J. Ecology, 81, 729-738, 1993.

Silver, W. L., et al., Effects of soil texture on belowground carbon and nutrient storage in a lowland Amazonian forest ecosystem, Ecosystems, 3, 193-209, 2000.

Steudler, P. A., et al., Consequences of forest-to-pasture conversion on $\mathrm{CH}_{4}$ fluxes in the Brazilian Amazon Basin, J. Geophys. Res., 101, 18,54718,554, 1996.

Veldkamp, E., and M. Keller, Nitrogen oxide emissions from a banana plantation in the humid tropics, J. Geophy. Res., 102, 15,889-15,898, 1997.

Verchot, L. V., et al., Land use change and biogeochemical controls of nitrogen oxide emissions from soil in eastern Amazonia, Global Biogeochem. Cycles, 13, 31-46, 1999.

Vogt, K. A., and H. Persson, Measuring growth and development of roots, in Techniques and approaches in forest tree ecophysiology, edited by J. P. Lassoie and T. M. Hinkley, 447-502, CRC Press, Boca Raton, Fl, 1991.

R. K. Varner, M. Keller, J. R. Robertson, H. Silva, and P. M. Crill, Complex Systems Research Center, Institute for the Study of Earth Oceans and Space, University of New Hampshire, Durham, NH, USA.

J. D. Dias, Fundacao Floresta Tropical, Santarem, Para, Brazil.

M. McGroddy, Department of Ecology and Evolutionary Biology, Princeton University, Princeton, NJ, USA.

W. L. Silver, Division of Ecosystem Sciences, Department of Environmental Science, Policy, and Management, University of California, Berkeley, CA, USA. 